\title{
Clickable PNA Probes for Imaging Human Telomeres and Poly(A) RNAs
}

\author{
Pramod M. Sabale, Uddhav B. Ambi, and Seergazhi G. Srivatsan*(i) \\ Department of Chemistry, Indian Institute of Science Education and Research (IISER), Pune, Doctor Homi Bhabha Road, Pune \\ 411008, India
}

\section{Supporting Information}

ABSTRACT: The ability to bind strongly to complementary nucleic acid sequences, invade complex nucleic acid structures, and resist degradation by cellular enzymes has made peptide nucleic acid (PNA) oligomers as very useful hybridization probes in molecular diagnosis. For such applications, the PNA oligomers have to be labeled with appropriate reporters as they lack intrinsic labels that can be used in biophysical assays. Although solid-phase synthesis is commonly used to attach reporters onto PNA, development of milder and modular labeling methods will provide access to PNA oligomers labeled with a wider range of biophysical tags. Here, we describe the establishment of a postsynthetic modification strategy based on bioorthogonal chemical reactions in functionalizing PNA oligomers in solution with a variety of tags. A toolbox composed of alkyne- and azide-modified monomers were site-specifically incorporated into PNA oligomers and postsynthetically click-functionalized with various tags, ranging from sugar, amino acid, biotin, to fluorophores, by using copper(I)-catalyzed azide-alkyne cycloaddition, strain-promoted azide-alkyne cycloaddition, and Staudinger ligation reactions. As a proof of utility of this method, fluorescent PNA hybridization probes were developed and used in imaging human telomeres in chromosomes and poly(A) RNAs in cells. Taken together, this simple approach of generating a wide range of functional PNA oligomers will expand the use of PNA in molecular diagnosis.

\section{INTRODUCTION}

The potential of peptide nucleic acid (PNA) in gene therapy has long been contemplated because of its resistance to cellular hydrolytic enzymes and ability to bind strongly to complementary DNA and RNA. ${ }^{1-6}$ In addition, the tendency to stabilize triple helix ${ }^{7,8}$ and invade complex secondary structures $^{9-11}$ has rendered PNA oligomers as very useful hybridization probes in molecular diagnosis. Needless to say, such applications greatly rely on PNA oligomers labeled with an appropriate reporter like a fluorophore, affinity tag, or magnetic resonance imaging agent. ${ }^{12-16}$ In particular, PNAs conjugated to fluorescent reporters have been frequently utilized in various hybridization assays for the detection, quantification, and visualization of specific nucleic acid sequences in cell-free and native cellular conditions. ${ }^{17-25}$

Probe-labeled PNA oligomers are commonly synthesized by using a procedure analogous to the solid-phase peptide synthesis protocol. Typically, native nucleobases attached to $\mathrm{N}$-(2-aminoethyl)glycine (aeg) or a similar backbone are sequentially added from the $\mathrm{C}$ terminus ( $3^{\prime}$-end) to $\mathrm{N}$ terminus ( $5^{\prime}$-end) on the solid support by using tertbutyloxycarbonyl (Boc) or fluorenylmethyloxycarbonyl chloride (Fmoc) chemistry. ${ }^{1,26}$ The desired label is then introduced at the $\mathrm{N}$ terminus by performing an acid-amine coupling reaction on the solid support before the final cleavage cum global deprotection step. ${ }^{12,13,27}$ This approach has been commonly used in preparing fluorescently modified PNA probes for imaging specific nucleic acid sequences in cells. Alternatively, base-modified monomers are incorporated into PNA oligomers at the desired position during solid-phase synthesis. ${ }^{28-33}$ However, this on-column labeling method has certain shortcomings. The tendency of many activated esters to undergo hydrolysis reduces the coupling efficiency, and certain modifications do not survive strong acid conditions used in the cleavage step (e.g., trifluoroacetic acid (TFA)/trifluoromethanesulfonic acid). Similar problems have also been encountered in both solid-phase peptide and oligonucleotide (ON) labeling methods. To circumvent these drawbacks, postsynthetic modification using chemoselective reactions has emerged as a valuable route to label glycans, proteins, and nucleic acids. ${ }^{34-44}$ In this approach, a small reactive handle, which is compatible with solid-phase or enzymatic labeling methods, is introduced into the oligomer and the desired label is attached by performing a chemoselective reaction between the reactive handle on the oligomer and the label containing the cognate reactive partner. This so-called "click chemistry" can be performed on the solid support as well as on the free oligomer in solution. ${ }^{45}$

Received: September 27, 2018

Accepted: October 31, 2018

Published: November 12, 2018 
Scheme 1. Synthesis of 5-ODU-Modified PNA Monomer 7

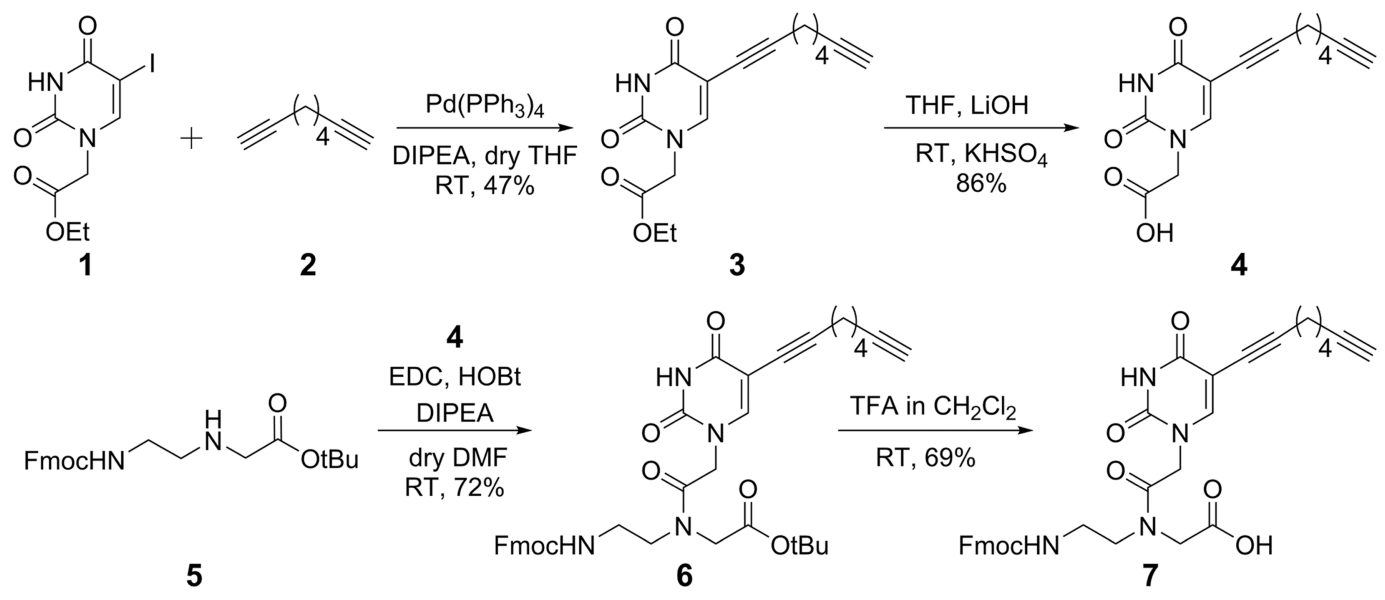

Scheme 2. Synthesis of Azide-Labeled Uracil PNA Monomer $14^{a}$

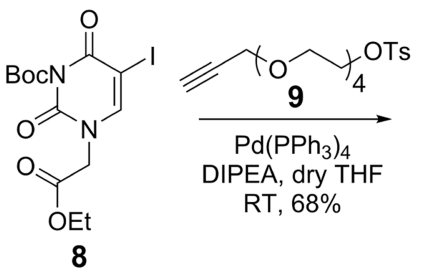<smiles>CCOC(=O)Cn1cc(C#CCOCC(C)C)c(=O)n(C(=O)OCC)c1=O</smiles><smiles>CCOC(=O)Cn1cc(C#CCOCC#N)c(=O)[nH]c1=O</smiles>

10

11

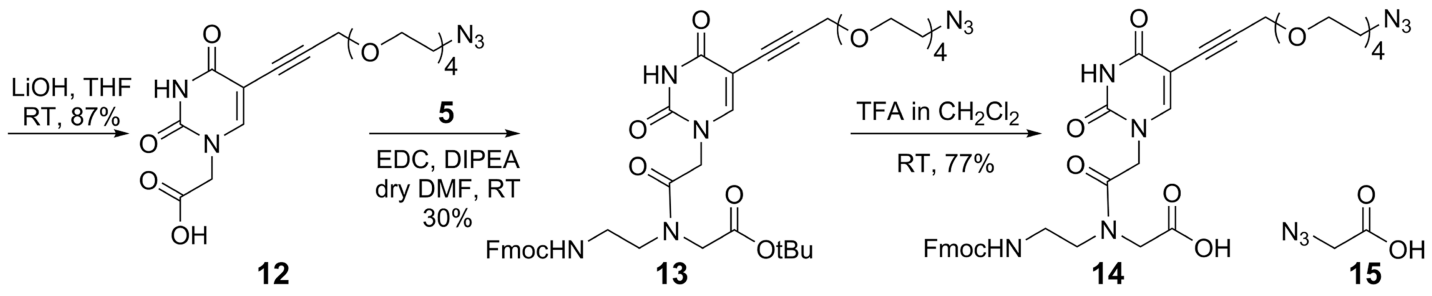

${ }^{a}$ Azidoacetic acid $\mathbf{1 5}$ was used for introducing azide group at the $\mathrm{N}$ terminus of PNA.

Several chemoselective reactions, including copper(I)catalyzed azide-alkyne cycloaddition (CuAAC), strain-promoted azide-alkyne cycloaddition (SPAAC), thiol-ene coupling, azide-phosphine Staudinger ligation, inverse electron demand Diels-Alder, and palladium-catalyzed reactions have been described for labeling biomolecules. ${ }^{34-44}$ In particular, azide-alkyne cycloaddition reaction has gained prominence as it is fast, highly chemoselective, and bioorthogonal, which has enabled its use in cell-free as well as in cellular systems. Initially, this bioconjugation method was performed on a solid support to prepare labeled PNA oligomers. $^{22,46-50}$ Subsequently, solution-phase click labeling was conceived, wherein PNAs conjugated to cell-penetrating peptides, mesoporous silica nanoparticles, cross-linking agents, and fluorophores were prepared. ${ }^{51-56}$ However, given the usefulness of PNA in molecular diagnosis, establishment of chemical labeling strategies, which will provide direct access to a repertoire of PNA probes in a modular fashion, is constantly needed.

Here, we describe the synthesis and site-specific incorporation of a clickable toolbox composed of alkyne- and azidemodified uracil PNA base analogs and azidoacetic acid as an azide surrogate. The alkyne- and azide-modified PNA oligomers were efficiently clicked with a variety of tags, ranging from sugar, amino acid, biotin, to fluorophores, by
CuAAC reaction. The ability of azide group to participate in different chemoselective reactions was further exploited in labeling PNA with biophysical probes in a modular fashion by using SPAAC and Staudinger ligation reactions. Using this labeling method, we designed fluorescent PNA hybridization probes to specifically visualize human telomeres in chromosomes and poly(A) tail-containing RNAs in cells. Further, the compatibility of clickable PNA oligomers to posthybridization labeling adds an advantage to this method as oligomers containing large reporters could potentially hamper the hybridization efficiency.

\section{RESULTS AND DISCUSSION}

Synthesis of Alkyne- and Azide-Modified Uracil PNA Base Analogs 7 and 14. The clickable uracil PNA base analogs containing the original aeg backbone were synthesized according to the steps illustrated in Schemes 1 and 2. In the monomer design, we have intentionally tethered the clickable component to the nucleobase via an alkyl or triethylene glycol linker so as to enhance the efficiency of the click reaction when incorporated into PNA oligomers. Further, the PNA analogs 7 and 14 contain a nonclickable internal alkyne, which can be used as a Raman-scattering label. ${ }^{57}$ The alkyne group displays a characteristic strong signal, which falls in the Raman-silent region of the cell. ${ }^{58}$ This unique bioorthogonal Raman label 
has recently been used in visualizing biomolecules, including nucleic acids and proteins, by the stimulated Raman-scattering imaging technique. ${ }^{59-61}$ Hence, these nucleobase analogs incorporated into PNA hybridization probes could potentially facilitate two-channel visualization of a specific nucleic acid sequence in cells by employing click chemistry (terminal alkyne or azide) and Raman spectroscopy (internal alkyne).

5-Iodouracil ethyl ester $1^{62}$ was reacted with octa-1,7-diyne 2 under Sonogashira coupling reaction conditions to give octadiyne-conjugated uracil (ODU) ethyl ester 3 (Scheme 1). The ester group was hydrolyzed in the presence of $\mathrm{LiOH}$ and coupled with a commercially available Fmoc aeg-PNA backbone 5 to give compound 6. Further treatment with TFA gave the ODU-modified PNA monomer 7 required for the solid-phase PNA synthesis.

5-Iodouracil ethyl ester 1 was Boc-protected (8) at the N3 position. $^{32}$ O-Tosylated tetraethylene glycol containing a terminal alkyne group (9) was prepared in two steps following a reported procedure. ${ }^{63}$ Compound 8 was coupled with 9 under Sonogashira cross-coupling reaction conditions, which was then converted into azide-modified uracil ester 11 by treating with $\mathrm{NaN}_{3}$ (Scheme 2). The ester was hydrolyzed and coupled with Fmoc aeg-PNA backbone 5, and then the tertiary butyl group was removed using TFA to afford the azide-modified uracil PNA building block 14.

Postsynthetic Modification of Alkyne- and AzideLabeled PNA Oligomers. The suitability of modified PNA base analogs for postsynthetic chemical labeling was evaluated by using model PNA oligomers containing OD-uracil (16), azido-uracil (17), and azido-acetamide (18, Figure 1). These

$\begin{array}{ll}16 & 7 \text { tactagcKK } \\ 17 & \text { 14tactagcKK } \\ 18 & \text { 15tactagcKK } \\ 19 & 15 \text { KKccctaaccctaaccctaaKK } \\ 20 & 7 \text { tttttttttKK } \\ 21 & \text { ccc7aaccctaaccctaaKK } \\ 22 & \text { ccctaaccctaaccctaaKK } \\ 23 & 5 ' \text { TTAGGGTTAGGGTTAGGG 3' }\end{array}$

Figure 1. Sequence of alkyne- (16) and azide-modified (17 and 18) model PNA oligomers. Sequence of azide- (19) and alkyne-modified (21) PNA probes complementary to the human telomeric DNA repeat. Alkyne-modified poly $(\mathrm{T})$ PNA probe $\mathbf{2 0}$ for visualizing poly(A) RNAs is shown. Sequence of control-unmodified PNA 22 complementary to the telomeric DNA ON repeat 23 is also shown. PNA sequences are written from $\mathrm{N}$ to $\mathrm{C}$ terminus in small letters. $\mathrm{K}$ represents lysine residue.

oligomers were prepared using lysine-loaded Rink amide resin and Fmoc-protected aeg-PNA monomers. PNA oligomers were synthesized with two C-terminal lysine residues to enhance the aqueous solubility. The oligomers were further purified by reversed phase high performance liquid chromatography (RP-HPLC) and characterized by mass analysis (Figure S1 and Table S1). The modified PNAs were subjected to CuAAC, SPAAC, and Staudinger ligation reactions in the presence of a variety of substrates containing cognate alkyne, azide, and phosphine reactive partners $(\mathbf{a}-\mathbf{i}$, Figure 2$)$. The substrates included different fluorophores, sugar, amino acid, and affinity tags.

CuAAC reaction was performed by incubating alkynemodified PNA 16 and azide-modified PNA 17 and 18 with azide substrates $\mathbf{a}-\mathbf{d}$ and alkyne substrates $\mathbf{e}-\mathbf{g}$, respectively
(Figures 2, 3, and 4). Reactions were carried out in the presence of a water-soluble $\mathrm{Cu}(\mathrm{I})$ stabilizing ligand, tris(3hydroxypropyltriazolylmethyl)amine (THPTA), $\mathrm{CuSO}_{4}$, and a reducing agent, sodium ascorbate, at $37{ }^{\circ} \mathrm{C}$ for $2 \mathrm{~h}$. The reaction mixture was resolved by RP-HPLC, and the clicked product was isolated and characterized by matrix assisted laser desorption ionization-time of flight (MALDI-TOF) mass analysis (Figures S2, S3, and Table S2). In a reaction with different azide substrates $(\mathbf{a}-\mathbf{d})$, the alkyne-modified PNA 16 was completely consumed within $2 \mathrm{~h}$ and respective clicked products were isolated in respectable yields (Table S2). Typically, a reaction performed at $15 \mathrm{nmol}$ scale of PNA 16 gave 5.8-7.8 nmol of the product $(16 \mathbf{a}-16 \mathrm{~d})$. CuAAC reaction between azide-modified PNA 17 and 18 with alkyne substrates $\mathbf{e}-\mathbf{g}$ proceeded to completion, and the products were isolated in moderate yields (Figure 4 and Table S2). The emission spectrum of naphthalimide-labeled PNA products (16a, 17e and 18e) also confirmed the fluorescence labeling by click reaction (Figure S4). Next, PNAs 17 and 18 were subjected to SPAAC reaction with biotin-cyclooctyne (h). The reaction completed in $1 \mathrm{~h}$, and the clicked products $17 \mathrm{~h}$ and $\mathbf{1 8 h}$ were recovered in good yields (Figure 5 and Table S3). Although Staudinger ligation between azido-uracilmodified PNA 17 and biotinylated triarylphosphine (i) was poor, reaction with azido-acetamide-modified PNA 18 gave good yields of the ligated product $\mathbf{1 8} \mathbf{i}$ (Table S3). Collectively, these results underscore the potential of the click-labeling approach in synthesizing various functionalized PNA oligomers in amounts sufficient for subsequent biophysical analysis.

Clicked-Labeled PNA Hybridization Probes Allow Visualization of Specific Nucleic Acid Sequences. Imaging Human Telomeric DNA Repeat Sequence. To illustrate the utility of this postsynthetic labeling method in visualizing nucleic acids, we first chose to target the human telomeres, which are present at the ends of chromosomes and protect them from end-to-end fusion and degradation. ${ }^{64,65}$ The human telomeres are composed of thousands of tandem hexameric nucleotide repeat (TTAGGG) $)_{n}$, which terminate into 100-200 nucleotide long 3' single-stranded overhang. ${ }^{66}$ Abnormal shortening of telomeric repeats and maintenance of telomere length by the telomerase activity can lead to genomic instability and tumor progression. ${ }^{67-69}$ Telomeric DNA repeat overhang has been shown to form G-quadruplex structures in vitro and in cellular environment. ${ }^{70-75}$ Recently, we developed a graphene oxide-based platform to detect telomeric DNA repeat in vitro by using the ability of a complementary PNA probe to invade G-quadruplex structure and form a stable duplex. ${ }^{76}$ Prompted by this key observation, we sought to use the postsynthetic labeling approach to develop a fluorescently labeled PNA hybridization probe to visualize telomeres on the chromosome ends.

An 18-mer azide-labeled PNA probe 19 complementary to the human telomeric DNA repeat sequence (TTAGGG) ${ }_{n}$ was synthesized (Figure 1 and Table S1). When subjected to CuAAC, SPAAC, and Staudinger ligation reactions with fluorescent and biotin substrates, we could isolate the clicked products in reasonable amounts (Figure 2 and Table S4). Although biotin-labeled PNA probes (19h and 19i) could be used for immunofluorescence staining, Alexa594-labeled PNA probe $(\mathbf{1 9 j})$ can be directly visualized post hybridization with telomeric DNA.

DLD-1 cells in culture were treated with colcemid to arrest the cell cycle in the metaphase stage. ${ }^{77}$ The cell suspension was 
<smiles>NCCCNc1ccc2c3c(cccc13)C(=O)N(CCO)C2=O</smiles>

a<smiles>NCCOC1OC(CO)[C@H](O)C(O)[C@H]1O</smiles><smiles>NCCCNC(=O)C(N)Cc1c[nH]c2ccccc12</smiles><smiles>CC(C)CC1SCC2NC(=O)NC21</smiles>

d

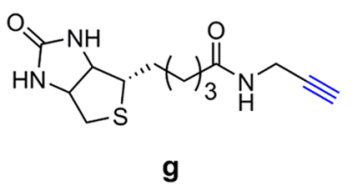

g<smiles>COC(=O)c1ccc(C(=O)NCCCOCCNC(=O)C=CC2SCC3NC(=O)NC32)cc1P(c1ccccc1)c1ccccc1</smiles><smiles>C#CCNC(=O)c1ccc(C2=c3cc4c(cc3Oc3cc5c(cc32)C(CO)=CC(C)(C)N5C)=[N+](C)C(C)(C)C=C4C(=O)O)c(C(=O)O)c1</smiles>

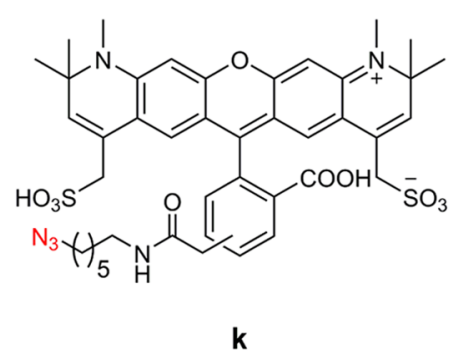

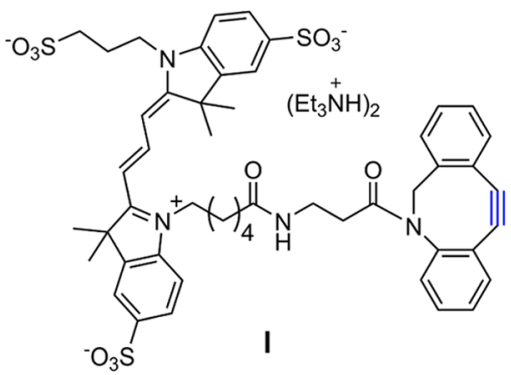

Figure 2. Azide-, alkyne-, and triarylphosphine-modified substrates $(\mathbf{a}-\mathbf{l})$ used in the postsynthetic PNA labeling by CuAAC, SPAAC, and Staudinger ligation reactions, respectively. See the Supporting Information for synthesis of substrates and commercial source.

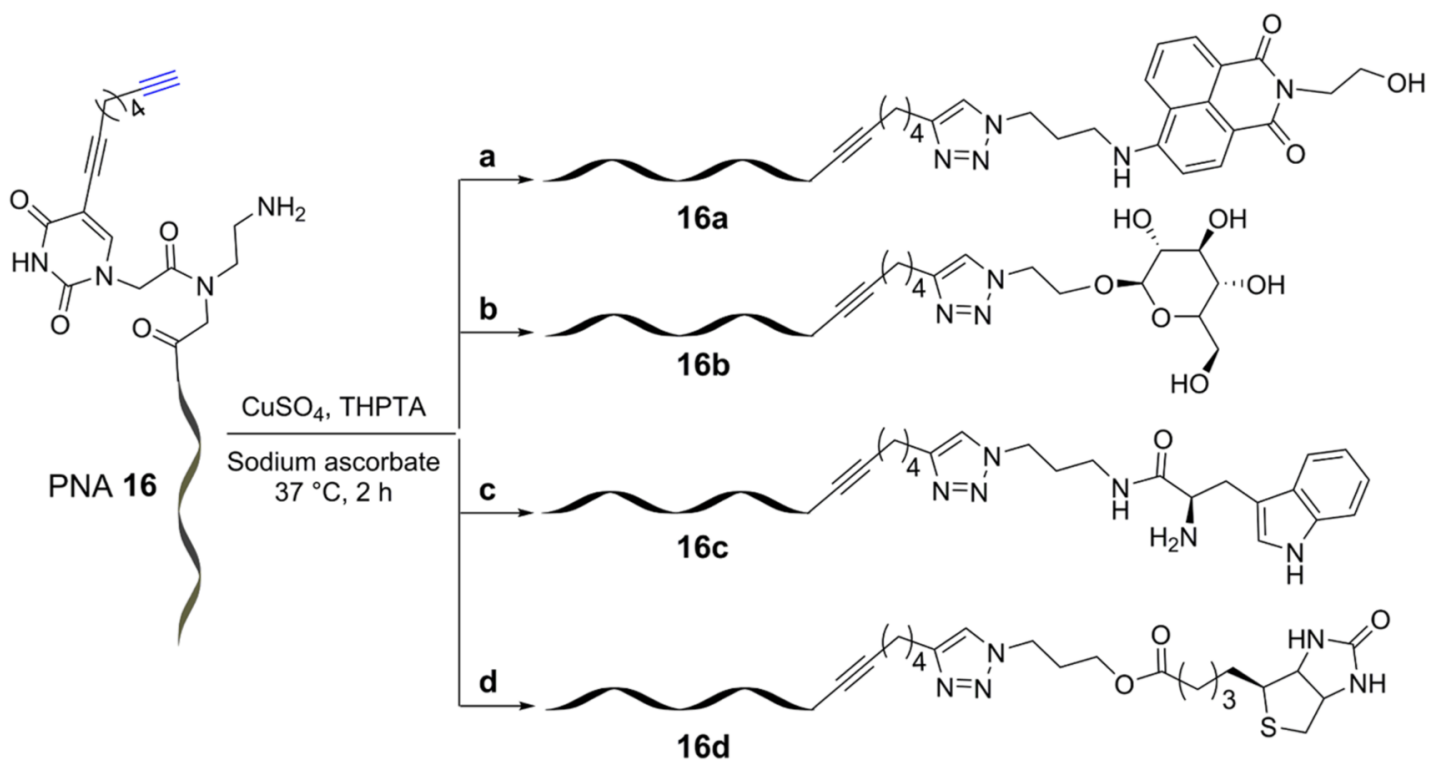

Figure 3. Postsynthetic chemical functionalization of alkyne-modified PNA oligomer $\mathbf{1 6}$ with azide substrates a-d by using the CuAAC reaction.

incubated in a hypotonic solution $(75 \mathrm{mM} \mathrm{KCl})$, and the pelleted cells were resuspended in a fixative solution. The cells were then dropped on a glass slide to prepare the metaphase chromosome spreads. Chromosomes were hybridized with freshly click-labeled Alexa PNA probe 19j and counterstained with 4',6-diamidino-2-phenylindole (DAPI). Images of the spread clearly indicated four fluorescent spots (red) consistent with the binding of the PNA probe to the telomeres present at the ends of chromosomes (Figure 6A). ${ }^{77,78} \mathrm{~A}$ commercially available FITC-labeled PNA probe prepared by acid-amine coupling also showed similar telomere staining pattern (green, Figure 6B). Notably, both the probes stained all chromosomes in a given spread, highlighting the comparable efficiency of the staining process by click-labeled and commercial PNA probes.

Imaging Poly $(A)$ RNAs. With the success of imaging telomeric DNA, we expanded the utility of click PNA labeling 


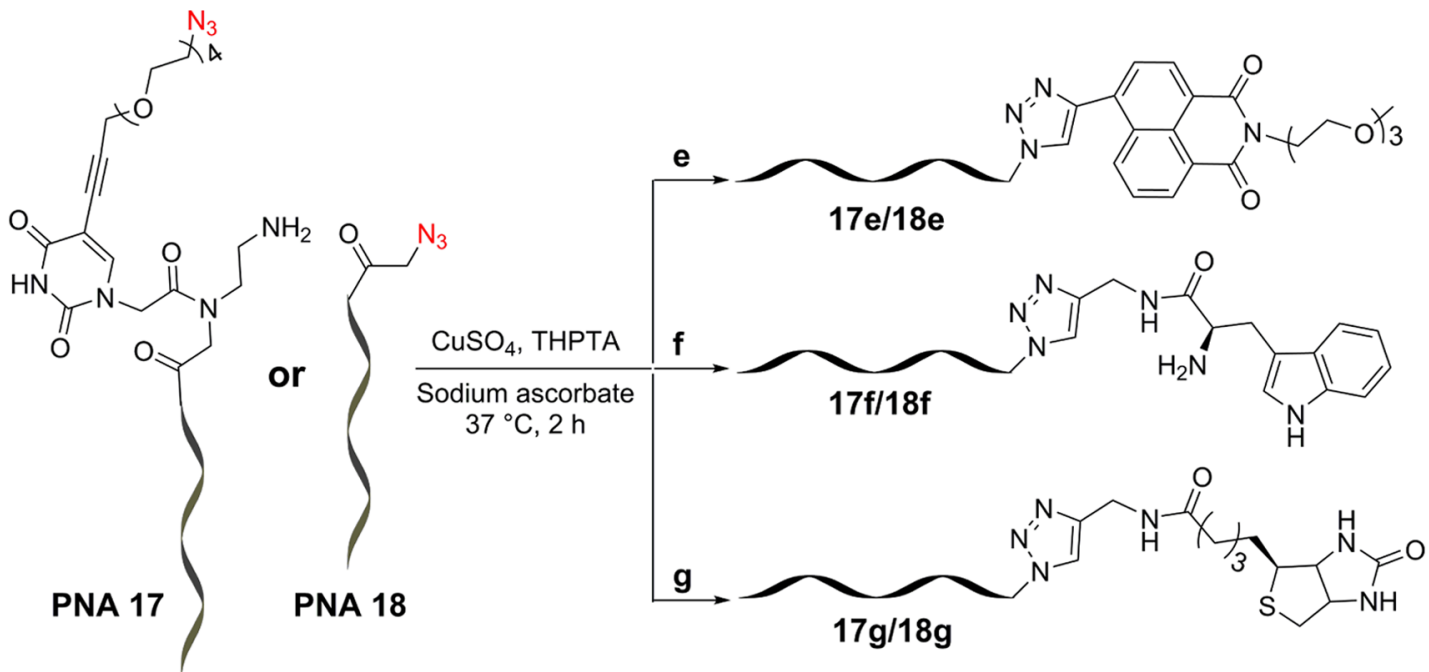

Figure 4. Postsynthetic chemical functionalization of azide-modified PNA oligomers $\mathbf{1 7}$ and $\mathbf{1 8}$ with alkyne substrates $\mathbf{e}-\mathrm{g}$ by using the CuAAC reaction.

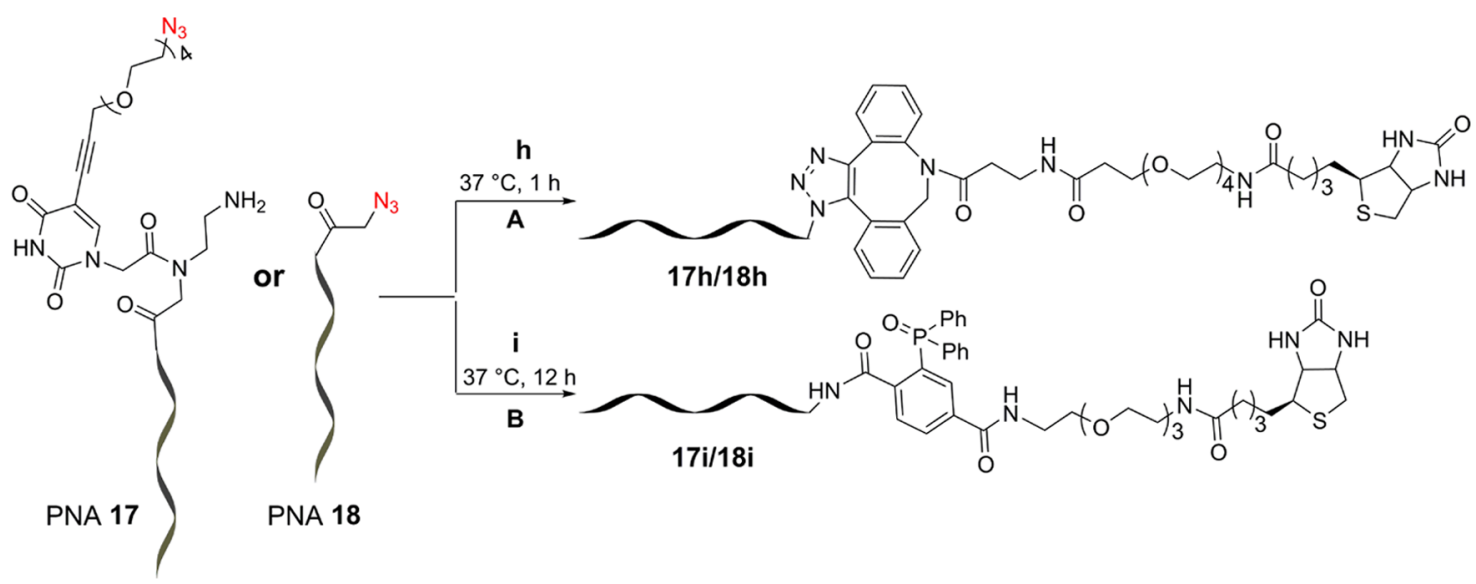

Figure 5. Postsynthetic chemical functionalization of azide-modified PNA oligomers $\mathbf{1 7}$ and $\mathbf{1 8}$ with biotin-cyclooctyne (h) and biotinylated triarylphosphine (i) by SPAAC and Staudinger ligation reactions, respectively.
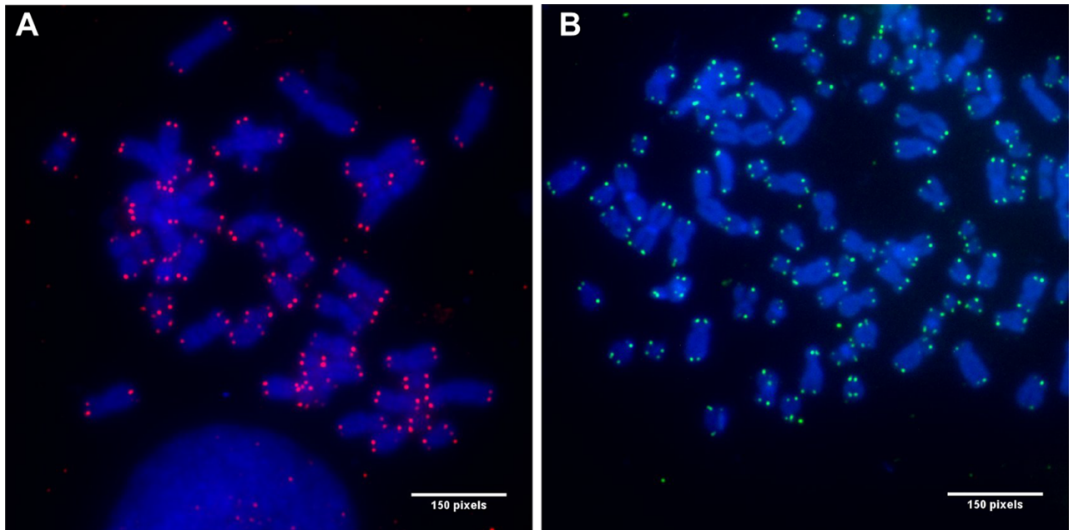

Figure 6. Imaging telomeric DNA repeats on the chromosomes using (A) Alexa594-labeled PNA probe 19j (red staining at the ends of chromosomes) and (B) FITC-labeled PNA probe (green staining at the ends of chromosomes). Metaphase spreads were prepared using DLD-1 cells and subjected to hybridization with PNA probes $(300 \mathrm{nM})$ in a hybridization buffer. For details see Methods section.

approach by developing a fluorescent poly(T) PNA probe to visualize cellular poly(A) RNAs. Poly(A) tailing is an important mRNA maturation process, which provides stability and promotes translation of mRNA. ${ }^{79,80} \operatorname{Poly}(\mathrm{A})$ tail length shortening causes mRNA splicing and initiates degradation process. Fluorescent poly $(\mathrm{T}) \mathrm{ON}$ probes are commonly used to track and visualize poly(A) RNAs inside cells, ${ }^{81-84}$ although the stability and hybridization efficiency of ON probes in a cellular environment is a concern. Since PNA oligomers are resistant to nucleases and proteases and they bind more 

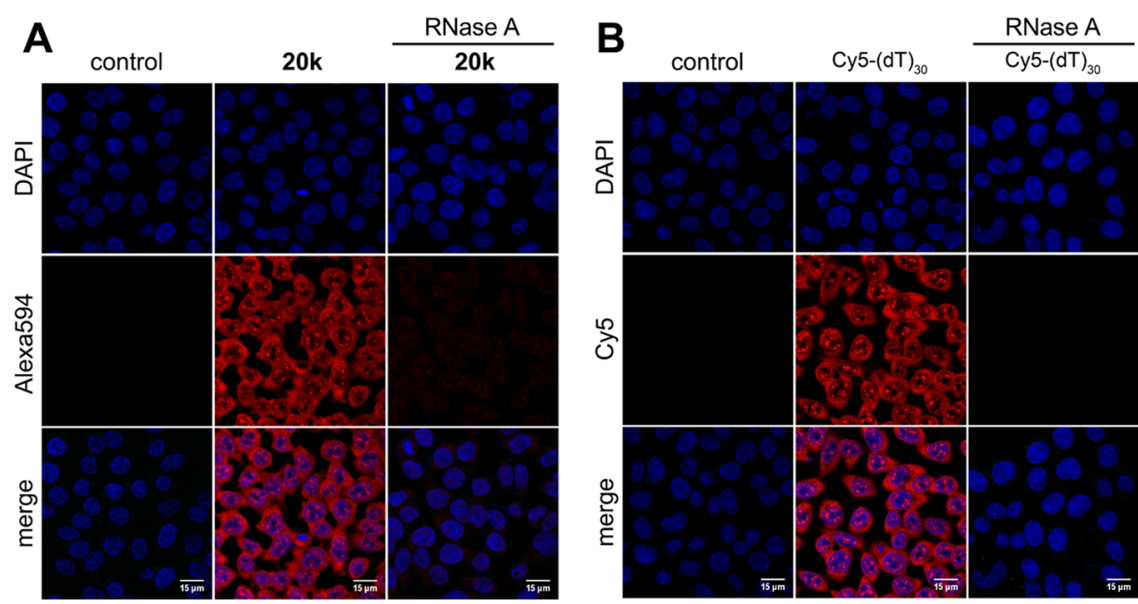

Figure 7. (A) Fluorescent PNA probe 20k (red) efficiently stains cellular poly(A) RNAs. RNase A treatment almost completely abolished poly(A) RNA staining by the PNA probe. (B) Similar staining pattern and loss of signal upon RNase A treatment was also observed when cells were hybridized with Cy5-( $\mathrm{dT})_{30}$, a commonly used probe for poly(A) RNA imaging.
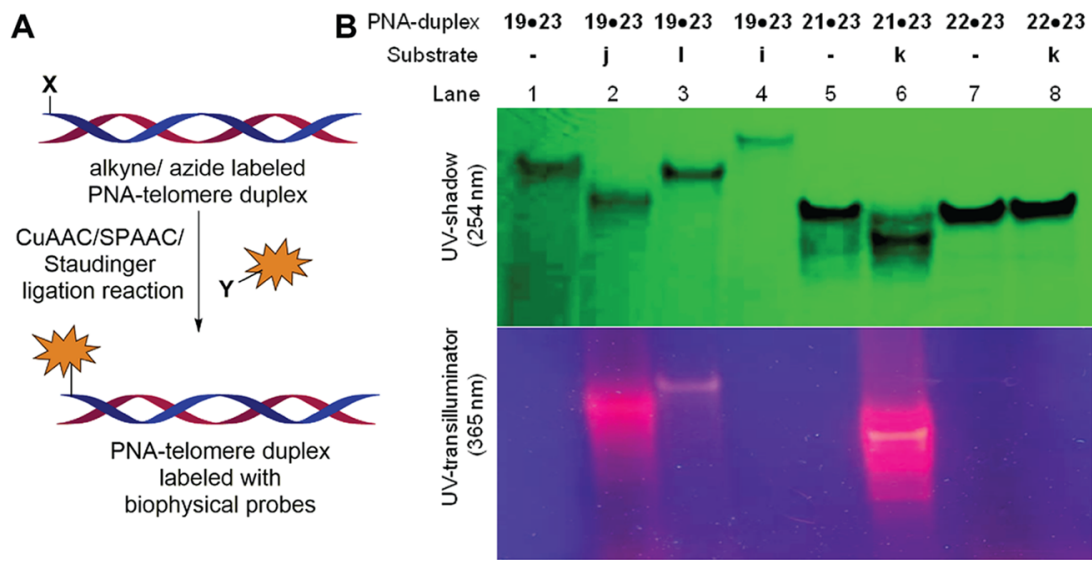

Figure 8. (A) Schematic illustration of postsynthetic chemical modification of PNA-telomere DNA ON heteroduplex using click reactions. (B) Reaction products were resolved by PAGE under nondenaturing conditions. Top: UV-shadow $(260 \mathrm{~nm})$ image of polyacrylamide gel. Bottom: Image of the gel as visualized by using a UV transilluminator $(365 \mathrm{~nm})$. Lane 1: Azide-labeled duplex 19.23. Lanes 2-4: CuAAC, SPAAC, and Staudinger ligation reactions between 19.23 and substrates $\mathbf{j}, \mathbf{l}$, and $\mathbf{i}$, respectively. Lane 5: Alkyne-labeled PNA-DNA duplex 21·23. Lane 6: Reaction with azide substrate $\mathbf{k}$. Lane 7: Unmodified PNA-DNA duplex 22-23. Lane 8: Control reaction with substrate $\mathbf{k}$. Lanes (2 and 6) corresponding to Alexa594-labeled duplexes are brighter than that corresponding to Cy5-labeled duplex (lane 3 ). This is due to the difference in excitation maximum of the fluorophores.

strongly to RNA than the complementary DNA ON, we synthesized a 12-mer fluorescent poly(T) PNA probe by clickreacting alkyne-modified PNA 20 with Alexa594 azide (k, red, Figure 2 and Table S4).

DLD-1 cells in culture were fixed, permeabilized, and hybridized with PNA 20k in a hybridization buffer at $37^{\circ} \mathrm{C}$ for $2.5 \mathrm{~h}$. Cells were washed and then DAPI-stained and imaged using a confocal microscope. The images revealed a punctate nuclear staining and uniform cytoplasmic staining in the Alexa594 channel (red, Figure 7A). As a positive control, cells were incubated with Cy5-(dT) $)_{30}$, a commonly used DNA ON probe for poly(A) RNA imaging. ${ }^{82,83}$ The DNA probe produced a staining pattern similar to that of the PNA probe (Figure 7B). The binding of PNA-DNA probes to poly(A) RNAs was further confirmed by RNase A treatment. ${ }^{85}$ Cells treated with RNase A and then hybridized with the probes revealed no detectable fluorescence signal from the cells (Figure 7).

Posthybridization Click Labeling of PNA-DNA ON Duplex. Although PNA binds to its target ON strongly, certain bulky modifications could potentially affect its binding efficiency. Hence, we attempted to perform click reactions on PNA-DNA heteroduplexes. Azide-modified (19) and alkynemodified (21) PNAs were hybridized with a complementary telomeric DNA ON repeat 23. Azide-labeled duplex 19.23 was reacted with Alexa alkyne (j), Cy5 cyclooctyne (1), and triarylphosphine biotin (i), and the products were analyzed by polyacrylamide gel electrophoresis (PAGE) under nondenaturing conditions. UV shadowing at $260 \mathrm{~nm}$ revealed almost complete labeling of the heteroduplex by CuAAC, SPAAC, and Staudinger ligation reactions (Figure 8, lanes 2-4). Further, UV shadowing at $365 \mathrm{~nm}$ revealed the fluorescence labeling by Alexa and Cy5 alkynes by click reaction (lanes 2 and 3). Similarly, alkyne-labeled PNA-DNA duplex 21.23 reacted quite efficiently with Alexa azide substrate $\mathbf{k}$ (lane 6). A control reaction between unmodified PNA-DNA duplex (22.23) and Alexa azide $\mathbf{k}$ did not produce any fluorescent click product, substantiating the high chemoselectivity of this labeling method. It is important to mention here that the observed mobility of click-labeled duplexes relative to the substrate 
duplexes is due to a combined effect of increased molecular weight and overall charge on the products.

\section{CONCLUSIONS}

We have established a postsynthetic chemical functionalization method to generate PNA probes by using bioorthogonal reactions like azide-alkyne cycloaddition and Staudinger ligation reactions. The clickable PNA oligomers, generated by incorporating azide- and alkyne-modified PNA base analogs, were used in installing a repertoire of biophysical tags in a modular fashion by click reactions. This labeling method was further utilized in synthesizing fluorescent PNA hybridization probes complementary to the human telomeric DNA ON repeat and poly $(\mathrm{A})$ repeat, which enabled the specific visualization of human telomeres in chromosomes and poly(A) tail-containing RNAs in cells. Collectively, our results demonstrate that this PNA bioconjugation approach is modular and will complement existing methods by providing access to PNA probes for various applications.

\section{METHODS}

Postsynthetic Modification of Azide- and AlkyneModified PNA Oligomers by CuAAC Reaction. Catalyst mix was prepared by mixing a solution of THPTA $(4.2 \mu \mathrm{L}, 90$ $\mathrm{mM}), \mathrm{CuSO}_{4}(4.2 \mu \mathrm{L}, 45 \mathrm{mM})$, and sodium ascorbate $(4.2 \mu \mathrm{L}$, $90 \mathrm{mM}$ ) in water. This mixture was added to an aqueous solution of alkyne- or azide-modified PNA oligomer 16/17/18 $(25 \mu \mathrm{L}, 0.6 \mathrm{mM})$. Stock solutions $(7.5 \mathrm{mM})$ of azide $(\mathbf{a}-\mathbf{d})$ and alkyne $(\mathbf{e}-\mathbf{g})$ substrates were prepared in dimethyl sulfoxide (DMSO). Azide or alkyne substrate $(10 \mu \mathrm{L}, 7.5$ $\mathrm{mM}$ ) was added to the reaction mixture, and the volume was adjusted to $50 \mu \mathrm{L}$ by adding water. The final concentration of reaction components was the following: THPTA $(7.50 \mathrm{mM})$, $\mathrm{CuSO}_{4}(3.75 \mathrm{mM})$, sodium ascorbate $(7.50 \mathrm{mM})$, PNA oligomer $(0.30 \mathrm{mM}, 15 \mathrm{nmol})$, azide or alkyne substrate $(1.5$ $\mathrm{mM})$, and DMSO (20\%). The reaction mixture was incubated at $37{ }^{\circ} \mathrm{C}$ for $2 \mathrm{~h}$ on a thermomixer $(500 \mathrm{rpm})$. The clicked product was purified by RP-HPLC (Figure S2). The peak corresponding to the clicked product was isolated and characterized by MALDI-TOF mass analysis. For the structure of clicked products, see Figures 3 and 4, and for yield and mass data, see Table S2.

Postsynthetic Modification of Azide-Modified PNA Oligomers by SPAAC Reaction with Biotin-Cyclooctyne h. A solution of azide-modified PNA oligomer 17/18 in water $(12.5 \mu \mathrm{L}, 0.6 \mathrm{mM})$ was mixed with cyclooctyne substrate $\mathbf{h}$ $(2.25 \mu \mathrm{L}, 10 \mathrm{mM})$ dissolved in DMSO. DMSO $(2.27 \mu \mathrm{L})$ was added to the above reaction mixture, and the total volume was adjusted to $25 \mu \mathrm{L}$ by adding water. The final concentration of PNA oligomers was $0.3 \mathrm{mM}(7.5 \mathrm{nmol})$, cyclooctyne substrate h was $0.9 \mathrm{mM}$, and DMSO was $20 \%$. The reaction mixture was incubated at $37{ }^{\circ} \mathrm{C}$ for $1 \mathrm{~h}$, and the clicked product was purified by RP-HPLC. The peak corresponding to the product was isolated and characterized by MALDI-TOF mass analysis. For the structure of clicked products, see Figure 5, and for yield and mass data, see Table S3.

Postsynthetic Modification of Azide-Modified PNA Oligomers by Staudinger Ligation Reaction with Biotinylated Triarylphosphine Substrate i. A solution of azide-modified PNA oligomer 17/18 $(6.0 \mu \mathrm{L}, 1.0 \mathrm{mM})$ in water was mixed with $50 \mathrm{mM}$ phosphate-buffered saline (PBS) buffer $(10 \mu \mathrm{L}, \mathrm{pH} 8.0)$. Biotinylated phosphine substrate i (1.2 $\mu \mathrm{L}, 50 \mathrm{mM})$ in DMSO was added to the above solution and mixed well. DMSO $(8.8 \mu \mathrm{L})$ was added to the above reaction mixture, and the volume was adjusted to $50 \mu \mathrm{L}$ by adding water. The final concentration of reaction components was the following: PNA (0.12 mM, $6 \mathrm{nmol})$, i $(1.2 \mathrm{mM})$, and DMSO (20\%). The reaction mixture was incubated at $37{ }^{\circ} \mathrm{C}$ for $12 \mathrm{~h}$, and the ligated product was purified by RP-HPLC. The ligated product was isolated and characterized by MALDI-TOF mass analysis. For the structure of ligated products, see Figure 5, and for yield and mass data, see Table S3.

Imaging Telomeric DNA Repeats. Metaphase Chromosome Spreads. DLD-1 (Human colon cancer cells ATCC CCL-221) cells were cultured in RPMI1640 medium (Gibco by Life Technologies, 61870-036) supplemented with $10 \%$ fetal bovine serum (Gibco by Life Technologies, 10437028) and penicillin-streptomycin (Gibco by Life Technologies, 15070-063) under humidified atmosphere at $37{ }^{\circ} \mathrm{C}$ with $5 \%$ $\mathrm{CO}_{2}$. Cells were seeded in a $100 \mathrm{~mm}$ culture dish and allowed to grow till $70 \%$ confluency, and then cells were further treated with Colcemid (Roche 10295892001) $0.1 \mu \mathrm{g} / \mathrm{mL}$ for $90 \mathrm{~min}$ in an incubator. Subsequently, cells were trypsinized to form a single-cell suspension and incubated in a hypotonic solution $(75 \mathrm{mM} \mathrm{KCl})$. Cells were then pelleted by centrifugation and resuspended in fixative solution (methanol/acetic acid $=3: 1$ ). Metaphase spreads were prepared by dropping the cell suspension $(10 \mu \mathrm{L})$ in fixative on a glass slide under moist condition. Glass slides with spreads were then air-dried and stored at room temperature until use.

Hybridization and Imaging. Slides containing metaphase spreads were heated at $65{ }^{\circ} \mathrm{C}$ for $10 \mathrm{~min}$ and immersed in $1 \times$ PBS for $15 \mathrm{~min}$. Subsequently, metaphase spreads were fixed using $4 \%$ formaldehyde in $1 \times$ PBS (50 $\mathrm{mM} \mathrm{MgCl}_{2}$ ) for 15 min. Slides were then washed with $1 \times$ PBS for 5 min twice and treated with $3 \mu \mathrm{g} / \mu \mathrm{L}$ RNase A for $3 \mathrm{~h}$ in a moist condition at $37{ }^{\circ} \mathrm{C}$. After RNase treatment, slides were washed with $2 \times$ saline-sodium citrate (SSC) buffer, autoclave water, and then immersed in $0.005 \%$ pepsin solution prepared in $10 \mathrm{mM} \mathrm{HCl}$ ( $\mathrm{pH} \mathrm{2.0)}$ for $5 \mathrm{~min}$ at $37^{\circ} \mathrm{C}$. Next, the slides were washed with $1 \times$ PBS and dipped in fixative (formaldehyde) solution for 10 min, as mentioned before. Slides were then washed with $1 \times$ PBS for 5 min twice and allowed to dehydrate in the presence of chilled ethanol series (70, 90, and $100 \%$ ) for $5 \mathrm{~min}$. Above slides were air-dried and subjected to hybridization with Alexa594-labeled PNA probe 19j or FITC-labeled Pangene PNA probe $(300 \mathrm{nM})$ in the hybridization buffer $[70 \%$ formamide, $20 \mathrm{mM}$ Tris ( $\mathrm{pH} 7.4$ ), $20 \mathrm{mM} \mathrm{Na}_{2} \mathrm{HPO}_{4}$ ( $\mathrm{pH} 7.4$ ), and $0.1 \mu \mathrm{g} / \mathrm{mL}$ salmon sperm DNA in $2 \times$ SSC buffer] at 85 ${ }^{\circ} \mathrm{C}$ for $6 \mathrm{~min}$. The above slides were then incubated for $12 \mathrm{~h}$ at $37{ }^{\circ} \mathrm{C}$ in a moist condition.

After hybridization, slides were washed with wash buffer I (70\% formamide and $10 \mathrm{mM}$ Tris $\mathrm{pH} \mathrm{7.2)} \mathrm{twice} \mathrm{for} 15 \mathrm{~min}$ and then with wash buffer II (70\% formamide, $50 \mathrm{mM}$ Tris $\mathrm{pH}$ 7.4, $150 \mathrm{mM} \mathrm{NaCl}$, and $0.05 \%$ Tween 20 ) twice for $10 \mathrm{~min}$. Slides were then dehydrated with ethanol series as mentioned earlier and air-dried. Metaphase spreads were counterstained with DAPI in $2 \times$ SSC for $3 \mathrm{~min}$ and washed with $0.1 \times$ SSC. Further, $7 \mu \mathrm{L}$ of antifade mounting media was added to the spreads on the slide, covered with coverslips, and sealed with nail polish. Cells were imaged using Zeiss Axio Imager Z1 with oil immersion using $100 \times$ lens.

Imaging Cellular Poly(A) RNAs. DLD-1 cells were cultured in RPMI1640 medium (Gibco by Life Technologies, 61870-036) supplemented with $10 \%$ fetal bovine serum 
(Gibco by Life Technologies, 10437028) and penicillinstreptomycin (Gibco by Life Technologies, 15070-063) under humidified atmosphere at $37{ }^{\circ} \mathrm{C}$ with $5 \% \mathrm{CO}_{2}$. Cells $(0.1-0.3$ million) were seeded on coverslips placed in a 12 -well plate. The cells were allowed to grow for nearly $48 \mathrm{~h}$ before hybridization experiment.

Fluorescence Hybridization Assay. Cells grown on coverslips were washed with $500 \mu \mathrm{L}$ of $1 \times$ PBS $\left(10 \mathrm{mM} \mathrm{Na}_{2} \mathrm{HPO}_{4}\right.$, $1.8 \mathrm{mM} \mathrm{KH} \mathrm{KO}_{4}, 2.7 \mathrm{mM} \mathrm{KCl}, 137 \mathrm{mM} \mathrm{NaCl}, 500 \mu \mathrm{M}$ vanadylribonucleoside complex (VRC), $\mathrm{pH} 7.4$ ) and fixed in $500 \mu \mathrm{L}$ of $4 \%$ paraformaldehyde containing $500 \mu \mathrm{M}$ VRC for 15 min. Subsequently, cells were permeabilized with $95 \%$ chilled methanol for $5 \mathrm{~min}$. Cells were then washed with 500 $\mu \mathrm{L}$ of $2 \times$ SSC buffer ( $0.3 \mathrm{M}$ sodium citrate, $0.03 \mathrm{M}$ sodium chloride, $500 \mu \mathrm{M}$ VRC, $\mathrm{pH}$ 7.4). The coverslip was placed upside down on a Parafilm strip containing $50 \mu \mathrm{L}$ of hybridization buffer $(10 \%(\mathrm{w} / \mathrm{v})$ dextran sulfate, $40 \%(\mathrm{v} / \mathrm{v})$ formamide, $30 \mathrm{ng} / \mu \mathrm{L}$ salmon sperm DNA, and $500 \mu \mathrm{M}$ VRC prepared in $2 \times$ SSC) and incubated for $30 \mathrm{~min}$ at $37^{\circ} \mathrm{C}$. Cells were washed with $500 \mu \mathrm{L}$ of $2 \times$ SSC buffer and hybridized with the fluorescent PNA probe $20 \mathrm{k}(1.0 \mu \mathrm{M})$ in hybridization buffer for $2.5 \mathrm{~h}$ at $37^{\circ} \mathrm{C}$. In a positive control experiment, cells were hybridized with $0.5 \mu \mathrm{M}$ Cy5- $(\mathrm{dT})_{30}$ under similar conditions. Cells were then washed with $500 \mu \mathrm{L}$ of $2 \times$ SSC and $500 \mu \mathrm{L}$ of $0.1 \times$ SSC buffer. Cells were counterstained with $500 \mu \mathrm{L}$ of DAPI ( $55 \mathrm{nM}$ in $2 \times$ SSC) for $3 \mathrm{~min}$ and washed with $500 \mu \mathrm{L}$ of $0.1 \times$ SSC. Coverslips were then placed on a microscope slide with $7 \mu \mathrm{L}$ of antifade mounting media and sealed with nail polish. Cells were imaged using a confocal laser scanning microscope with oil immersion using $40 \times$ lens. Images were acquired by using the following excitation and emission settings. DAPI $\left(\lambda_{\mathrm{ex}}=405 \mathrm{~nm}\right.$ and $\lambda_{\mathrm{em}}=420-480 \mathrm{~nm}$, blue channel); Alexa594-modified PNA probe $\left(\lambda_{\mathrm{ex}}=561 \mathrm{~nm}\right.$ and $\lambda_{\mathrm{em}}=570-680 \mathrm{~nm}$, red channel); and Cy5-(dT) $)_{30}$ probe ( $\lambda_{\mathrm{ex}}=633 \mathrm{~nm}$ and $\lambda_{\mathrm{em}}=640-760 \mathrm{~nm}$, red channel). Java ImageJ software was used to process the images.

RNase A Treatment. Cells were incubated in $500 \mu \mathrm{L}$ of RNase A $(0.5 \mu \mathrm{g} / \mathrm{mL}$ in $1 \times \mathrm{PBS})$ solution for $1 \mathrm{~h}$ at $37{ }^{\circ} \mathrm{C}$. Cells were washed with $500 \mu \mathrm{L}$ of $2 \times$ SSC and then hybridized with $0.5 \mu \mathrm{M}$ of Cy5-(dT) $)_{30}$ or $1.0 \mu \mathrm{M}$ of labeled PNA probe 20k, as mentioned above.

\section{ASSOCIATED CONTENT}

\section{S Supporting Information}

The Supporting Information is available free of charge on the ACS Publications website at DOI: 10.1021/acsomega.8b02550.

Experimental procedure, characterization data, supporting figures and tables, and NMR spectra (PDF)

\section{AUTHOR INFORMATION}

\section{Corresponding Author}

*E-mail: srivatsan@iiserpune.ac.in.

\section{ORCID $\odot$}

Seergazhi G. Srivatsan: 0000-0001-5765-3967

Notes

The authors declare no competing financial interest.

\section{ACKNOWLEDGMENTS}

P.M.S. is grateful to CSIR, India for the graduate research fellowship. U.B.A. is supported by a grant from Wellcome
Trust-DBT India Alliance (IA/S/16/1/502360). Dr S.G.S. acknowledges DST, India (EMR/2014/000419) and Wellcome Trust-DBT India Alliance (IA/S/16/1/502360) for the research grants. We thank IISER, Pune microscopy facility for providing access to record cell images.

\section{REFERENCES}

(1) Ganesh, K. N.; Nielsen, P. E. Peptide nucleic acids: analogs and derivatives. Curr. Org. Chem. 2000, 4, 931-943.

(2) Nielsen, P. E. Peptide nucleic acids (PNA) in chemical biology and drug discovery. Chem. Biodiversity 2010, 7, 786-803.

(3) Rozners, E. Recent advances in chemical modification of peptide nucleic acids. J. Nucleic Acids 2012, No. 518162.

(4) Gupta, A.; Mishra, A.; Puri, N. Peptide nucleic acids: Advanced tools for biomedical applications. J. Biotechnol. 2017, 259, 148-159.

(5) Ricciardi, A. S.; Quijano, E.; Putman, R.; Mark Saltzman, W.; Glazer, P. M. Peptide nucleic acids as a tool for site-specific gene editing. Molecules 2018, 23, No. 632.

(6) Demidov, V. V.; Potaman, V. N.; Frank-Kamenetskii, M. D.; Egholm, M.; Buchardt, O.; Sonnichsen, S. H.; Nielsen, P. E. Stability of peptide nucleic acids in human serum and cellular extracts. Biochem. Pharmacol. 1994, 48, 1310-1313.

(7) Betts, L.; Josey, J. A.; Veal, J. M.; Jordan, S. R. A nucleic acid triple helix formed by a peptide nucleic acid-DNA complex. Science 1995, 270, 1838-1841.

(8) Endoh, T.; Hnedzko, D.; Rozners, E.; Sugimoto, N. Nucleobasemodified PNA suppresses translation by forming a triple helix with a hairpin structure in mRNA in vitro and in cells. Angew. Chem., Int. Ed. 2016, 55, 899-903.

(9) Peffer, N. J.; Hanvey, J. C.; Bisi, J. E.; Thomson, S. A.; Hassman, C. F.; Noble, S. A.; Babiss, L. E. Strand-invasion of duplex DNA by peptide nucleic acid oligomers. Proc. Natl. Acad. Sci. U.S.A. 1993, 90, $10648-10652$.

(10) Wittung, P.; Nielsen, P.; Nordén, B. Direct observation of strand invasion by peptide nucleic acid (PNA) into double-stranded DNA. J. Am. Chem. Soc. 1996, 118, 7049-7054.

(11) Kaihatsu, K.; Braasch, D. A.; Cansizoglu, A.; Corey, D. R. Enhanced strand invasion by peptide nucleic acid-peptide conjugates. Biochemistry 2002, 41, 11118-11125.

(12) Amirkhanov, N. V.; Dimitrov, I.; Opitz, A. W.; Zhang, K.; Lackey, J. P.; Cardi, C. A.; Lai, S.; Wagner, N. J.; Thakur, M. L.;

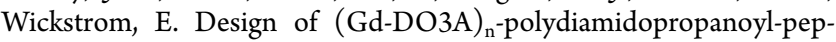
tide nucleic acid-D(Cys-Ser-Lys-Cys) magnetic resonance contrast agents. Biopolymers 2008, 89, 1061-1076.

(13) Mishra, R.; Su, W.; Pohmann, R.; Pfeuffer, J.; Sauer, M. G.; Ugurbil, K.; Engelmann, J. Cell-penetrating peptides and peptide nucleic acid-coupled MRI contrast agents: evaluation of cellular delivery and target binding. Bioconjugate Chem. 2009, 20, 1860-1868.

(14) Shiraishi, T.; Deborggraeve, S.; Büscher, P.; Nielsen, P. E. Sensitive detection of nucleic acids by PNA hybridization directed colocalization of fluorescent beads. Artif. DNA: PNA XNA 2011, 2, 6066.

(15) Torres, A. G.; Fabani, M. M.; Vigorito, E.; Williams, D.; AlObaidi, N.; Wojciechowski, F.; Hudson, R. H. E.; Seitz, O.; Gait, M. J. Chemical structure requirements and cellular targeting of microRNA122 by peptide nucleic acids anti-miRs. Nucleic Acids Res. 2012, 40, $2152-2167$.

(16) Beh, C. W.; Zhang, Y.; Zheng, Y.-L.; Sun, B.; Wang, T.-H. Fluorescence spectroscopic detection and measurement of single telomere molecules. Nucleic Acids Res. 2018, No. e117.

(17) Socher, E.; Bethge, L.; Knoll, A.; Jungnick, N.; Herrmann, A.; Seitz, O. Low-noise stemless PNA beacons for sensitive DNA and RNA detection. Angew. Chem., Int. Ed. 2008, 47, 9555-9559.

(18) Tedeschi, T.; Tonelli, A.; Sforza, S.; Corradini, R.; Marchelli, R. A pyrenyl-PNA probe for DNA and RNA recognition. Artif. DNA: PNA \& XNA 2010, 1, 83-89.

(19) Kam, Y.; Rubinstein, A.; Nissan, A.; Halle, D.; Yavin, E. Detection of endogenous K-ras mRNA in living cells at a single base 
resolution by a PNA molecular beacon. Mol. Pharmaceutics 2012, 9, 685-693.

(20) Kummer, S.; Knoll, A.; Socher, E.; Bethge, L.; Herrmann, A.; Seitz, O. PNA FIT-probes for the dual color imaging of two viral mRNA targets in influenza H1N1 infected live cells. Bioconjugate Chem. 2012, 23, 2051-2060.

(21) Sonar, M. V.; Wampole, M. E.; Jin, Y.-Y.; Chen, C.-P.; Thakur, M. L.; Wickstrom, E. Fluorescence detection of KRAS2 mRNA hybridization in lung cancer cells with PNA-peptides containing an internal thiazole orange. Bioconjugate Chem. 2014, 25, 1697-1708.

(22) Barluenga, S.; Winssinger, N. PNA as a biosupramolecular tag for programmable assemblies and reactions. Acc. Chem. Res. 2015, 48, 1319-1331.

(23) Holtzer, L.; Oleinich, I.; Anzola, M.; Lindberg, E.; Sadhu, K. K.; Gonzalez-Gaitan, M.; Winssinger, N. Nucleic acid templated chemical reaction in a live vertebrate. ACS Cent. Sci. 2016, 2, 394-400.

(24) Hövelmann, F.; Seitz, O. DNA stains as surrogate nucleobases in fluorogenic hybridization probes. Acc. Chem. Res. 2016, 49, 714723.

(25) Vilaivan, T. Fluorogenic PNA probes. Beilstein J. Org. Chem. 2018, 14, 253-281.

(26) Jain, D. R.; Anandi, V. L.; Lahiri, M.; Ganesh, K. N. Influence of pendant chiral $\mathrm{C}^{\gamma}$-(alkylideneamino/guanidino) cationic side-chains of PNA backbone on hybridization with complementary DNA/RNA and cell permeability. J. Org. Chem. 2014, 79, 9567-9577.

(27) Hnedzko, D.; McGee, D. W.; Rozners, E. Synthesis and properties of peptide nucleic acid labeled at the N-terminus with HiLyte Fluor 488 fluorescent dye. Bioorg. Med. Chem. 2016, 24, 4199-4205.

(28) Gangamani, B. P.; Kumar, V. A. 2-Aminopurine peptide nucleic acids (2-apPNA): intrinsic fluorescent PNA analogues for probing PNA-DNA interaction dynamics. Chem. Commun. 1997, 1913-1914.

(29) Wojciechowski, F.; Hudson, R. H. E. Fluorescence and hybridization properties of peptide nucleic acid containing a substituted phenylpyrrolocytosine designed to engage guanine with an additional H-bond. J. Am. Chem. Soc. 2008, 130, 12574-12575.

(30) Boonlua, C.; Vilaivan, C.; Wagenknecht, H.-A.; Vilaivan, T. 5(Pyren-1-yl)uracil as a base-discriminating fluorescent nucleobase in pyrrolidinyl peptide nucleic acids. Chem. - Asian J. 2011, 6, 32513259.

(31) Müllar, S.; Strohmeier, J.; Diederichsen, U. 8-Vinylguanine nucleo amino acid: A fluorescent PNA building block. Org. Lett. 2012, $14,1382-1385$.

(32) St. Amant, A. H.; Hudson, R. H. E. Synthesis and oligomerization of Fmoc/Boc-protected PNA monomers of 2,6diaminopurine, 2-aminopurine and thymine. Org. Biomol. Chem. 2012, $10,876-881$.

(33) Sabale, P. M.; Srivatsan, S. G. Responsive fluorescent PNA analogue as a tool for detecting G-quadruplex motifs of oncogenes and activity of toxic ribosome-inactivating proteins. ChemBioChem 2016, 17, 1665-1673.

(34) Sletten, E. M.; Bertozzi, C. R. Bioorthogonal chemistry: fishing for selectivity in a sea of functionality. Angew. Chem., Int. Ed. 2009, 48, 6974-6998.

(35) Spicer, C. D.; Davis, B. G. Selective chemical protein modification. Nat. Commun. 2014, 5, No. 4740.

(36) El-Sagheer, A. H.; Brown, T. Click chemistry with DNA. Chem. Soc. Rev. 2010, 39, 1388-1405.

(37) Ren, X.; El-Sagheer, A. H.; Brown, T. Azide and transcyclooctene dUTPs: incorporation into DNA probes and fluorescent click-labelling. Analyst 2015, 140, 2671-2678.

(38) Ren, X.; El-Sagheer, A. H.; Brown, T. Efficient enzymatic synthesis and dual-colour fluorescent labelling of DNA probes using long chain azido-dUTP and BCN dyes. Nucleic Acids Res. 2016, 44, No. e79.

(39) Matyašovský, J.; Perlíková, P.; Malnuit, V.; Pohl, R.; Hocek, M. 2-Substituted dATP derivatives as building blocks for polymerasecatalyzed synthesis of DNA modified in the minor groove. Angew. Chem., Int. Ed. 2016, 55, 15856-15859.
(40) Panattoni, A.; Pohl, R.; Hocek, M. Flexible alkyne-linked thymidine phosphoramidites and triphosphates for chemical or polymerase synthesis and fast postsynthetic DNA functionalization through copper-catalyzed alkyne-azide 1,3-dipolar cylcoaddition. Org. Lett. 2018, 20, 3962-3965.

(41) George, J. T.; Srivatsan, S. G. Posttranscriptional chemical labeling of RNA by using bioorthogonal chemistry. Methods 2017, $120,28-38$.

(42) George, J. T.; Srivatsan, S. G. Vinyluridine as a versatile chemoselective handle for the posttranscriptional chemical functionalization of RNA. Bioconjugate Chem. 2017, 28, 1529-1536.

(43) Walunj, M. B.; Tanpure, A. A.; Srivatsan, S. G. Posttranscriptional labeling by using Suzuki-Miyaura cross-coupling generates functional RNA probes. Nucleic Acids Res. 2018, 46, No. e65.

(44) Kalia, D.; Pawar, S. P.; Thopate, J. S. Stable and rapid thiol bioconjugation by light-triggered thiomaleimide ring hydrolysis. Angew. Chem., Int. Ed. 2017, 56, 1885-1889.

(45) Gramlich, P. M. E.; Wirges, C. T.; Manetto, A.; Carell, T. Postsynthetic DNA modification through the copper-catalyzed azidealkyne cycloaddition reaction. Angew. Chem., Int. Ed. 2008, 47, 83508358.

(46) Gasser, G.; Jäger, K.; Zenker, M.; Bergmann, R.; Steinbach, J.; Stephan, H.; Metzler-Nolte, N. Preparation, ${ }^{99} \mathrm{~m}$ Tc-labeling and biodistribution studies of a PNA oligomer containing a new ligand derivative of $2,2^{\prime}$-dipicolylamine. J. Inorg. Biochem. 2010, 104, 11331140.

(47) Chouikhi, D.; Barluenga, S.; Winssinger, N. Clickable peptide nucleic acids (cPNA) with tunable affinity. Chem. Commun. 2010, 46, 5476-5478.

(48) St. Amant, A. H.; Engbers, C.; Hudson, R. H. E. A solid-phase CuAAC strategy for the synthesis of PNA containing nucleobase surrogates. Artif. DNA: PNA XNA 2013, 4, 4-10.

(49) Ditmangklo, B.; Boonlua, C.; Suparpprom, C.; Vilaivan, T. Reductive alkylation and sequential reductive alkylation-click chemistry for on-solid support modification of pyrrolidinyl peptide nucleic acid. Bioconjugate Chem. 2013, 24, 614-625.

(50) Wang, X.; Milne, M.; Martínez, F.; Scholl, T. J.; Hudson, R. H. E. Synthesis of a poly(Gd(III)-DOTA)-PNA conjugate as a potential MRI contrast agent via post-synthetic click chemistry functionalization. RSC Adv. 2017, 7, 45222-45226.

(51) Deuss, P. J.; Arzumanov, A. A.; Williams, D. L.; Gait, M. J. Parallel synthesis and splicing redirection activity of cell-penetrating peptide conjugate libraries of a PNA cargo. Org. Biomol. Chem. 2013, 11, 7621-7630.

(52) Ma, X.; Devi, G.; Qu, Q.; Kaixin Toh, D.-F.; Chen, G.; Zhao, Y. Intracellular delivery of antisense peptide nucleic acid by fluorescent mesoporous silica nanoparticles. Bioconjugate Chem. 2014, 25, 14121420.

(53) Flory, J. D.; Johnson, T.; Simmons, C. R.; Lin, S.; Ghirlanda, G.; Fromme, P. Purification and assembly of thermostable Cy5 labeled $\gamma$-PNAs into a 3D DNA nanocage. Artif. DNA: PNA XNA 2014, 5, 1-8.

(54) Manicardi, A.; Gyssels, E.; Corradinia, R.; Madder, A. FuranPNA: a mildly inducible irreversible interstrand crosslinking system targeting single and double stranded DNA. Chem. Commun. 2016, 52, 6930-6933.

(55) Gogoi, K.; Mane, M. V.; Kunte, S. S.; Kumar, V. A. A versatile method for the preparation of conjugates of peptides with DNA/ $\mathrm{PNA} /$ analog by employing chemo-selective click reaction in water. Nucleic Acids Res. 2007, 35, No. e139.

(56) Manicardi, A.; Accetta, A.; Tedeschi, T.; Sforza, S.; Marchelli, R.; Corradini, R. PNA bearing 5-azidomethyluracil. Artif. DNA: PNA XNA 2012, 3, 1-10.

(57) Sawant, A. A.; Mukherjee, P. P.; Jangid, R. K.; Galande, S.; Srivatsan, S. G. A clickable UTP analog for the posttranscriptional chemical labeling and imaging of RNA. Org. Biomol. Chem. 2016, 14, $5832-5842$. 
(58) Hong, S.; Chen, T.; Zhu, Y.; Li, A.; Huang, Y.; Chen, X. Livecell stimulated Raman scattering imaging of alkyne-tagged biomolecules. Angew. Chem., Int. Ed. 2014, 53, 5827-5831.

(59) Yamakoshi, H.; Dodo, K.; Okada, M.; Ando, J.; Palonpon, A.; Fujita, K.; Kawata, S.; Sodeoka, M. Imaging of EdU, an alkyne-tagged cell proliferation probe, by Raman microscopy. J. Am. Chem. Soc. 2011, 133, 6102-6105.

(60) Wei, L.; Hu, F.; Shen, Y.; Chen, Z.; Yu, Y.; Lin, C.-C.; Wang, M. C.; Min, W. Live-cell imaging of alkyne-tagged small biomolecules by stimulated Raman scattering. Nat. Methods 2014, 11, 410-412.

(61) Chen, Z.; Paley, D. W.; Wei, L.; Weisman, A. L.; Friesner, R. A.; Nuckolls, C.; Min, W. Multicolor live-cell chemical imaging by isotopically edited alkyne vibrational palette. J. Am. Chem. Soc. 2014, 136, 8027-8033.

(62) Beall, E.; Ulku, S.; Liu, C.; Wierzbinski, E.; Zhang, Y.; Bae, Y.; Zhang, P.; Achim, C.; Beratan, D. N.; Waldeck, D. H. Effects of the backbone and chemical linker on the molecular conductance of nucleic acid duplexes. J. Am. Chem. Soc. 2017, 139, 6726-6735.

(63) Zhu, S.; Zhang, J.; Vegesna, G.; Luo, F.-T.; Green, S.; Liu, H. Highly water-soluble neutral BODIPY dyes with controllable fluorescence quantum yields. Org. Lett. 2011, 13, 438-441.

(64) Blackburn, E. H. The end of the (DNA) line. Nat. Struct. Biol. 2000, 7, 847-850.

(65) Verdun, R. E.; Karlseder, J. Replication and protection of telomeres. Nature 2007, 447, 924-931.

(66) Wright, W. E.; Tesmer, V. M.; Huffman, K. E.; Levene, S. D.; Shay, J. W. Normal human chromosomes have long G-rich telomeric overhangs at one end. Genes Dev. 1997, 11, 2801-2809.

(67) O'Sullivan, R. J.; Karlseder, J. Telomeres: protecting chromosomes against genome instability. Nat. Rev. Mol. Cell Biol. 2010, 11, 171-181.

(68) Harley, C. B.; Futcher, A. B.; Greider, C. W. Telomeres shorten during ageing of human fibroblasts. Nature 1990, 345, 458-460.

(69) Shay, J. W.; Roninson, I. B. Hallmarks of senescence in carcinogenesis and cancer therapy. Oncogene 2004, 23, 2919-2933.

(70) Tran, P. L. T.; Mergny, J.-L.; Alberti, P. Stability of telomeric G-quadruplexes. Nucleic Acids Res. 2011, 39, 3282-3294.

(71) Xu, Y.; Komiyama, M. Evidence for G-quadruplex DNA in human cells. ChemBioChem 2013, 14, 927-928.

(72) Henderson, A.; Wu, Y.; Huang, Y. C.; Chavez, E. A.; Platt, J.; Johnson, F. B.; Brosh, R. M., Jr.; Sen, D.; Lansdrop, P. M. Detection of G-quadruplex DNA in mammalian cells. Nucleic Acids Res. 2014, $42,860-869$.

(73) Biffi, G.; Tannahill, D.; McCafferty, J.; Balasubramanian, S. Quantitative visualization of DNA G-quadruplex structures in human cells. Nat. Chem. 2013, 5, 182-186.

(74) Liu, H.-Y.; Zhao, Q.; Zhang, T.-P.; Wu, Y.; Xiong, Y.-X.; Wang, S.-K.; Ge, Y.-L.; He, J.-H.; Lv, P.; Ou, T.-M.; Tan, J.-H.; Li, D.; Gu, L.Q.; Ren, J.; Zhao, Y.; Huang, Z.-S. Conformation selective antibody enables genome profiling and leads to discovery of parallel Gquadruplex in human telomeres. Cell Chem. Biol. 2016, 23, 12611270.

(75) Manna, S.; Sarkar, D.; Srivatsan, S. G. A dual-app nucleoside probe provides structural insights into the human telomeric overhang in live cells. J. Am. Chem. Soc. 2018, 140, 12622-12633.

(76) Sabale, P. M.; George, J. T.; Srivatsan, S. G. A base-modified PNA-graphene oxide platform as a turn-on fluorescence sensor for the detection of human telomeric repeats. Nanoscale 2014, 6, 1046010469.

(77) Lansdorp, P. M.; Verwoerd, N. P.; van de Rijke, F. M.; Dragowska, V.; Little, M.-T.; Dirks, R. W.; Raap, A. K.; Tanke, H. J. Heterogeneity in telomere length of human Chromosomes. Hum. Mol. Genet. 1996, 5, 685-691.

(78) Pham, H. H.; Murphy, C. T.; Sureshkumar, G.; Ly, D. H.; Opresko, P. L.; Armitage, B. A. Cooperative hybridization of $\gamma$ PNA miniprobes to a repeating sequence motif and application to telomere analysis. Org. Biomol. Chem. 2014, 12, 7345-7354.

(79) Beilharz, T. H.; Preiss, T. Transcriptome-wide measurement of mRNA polyadenylation state. Methods 2009, 48, 294-300.
(80) Subtelny, A. O.; Eichhorn, S. W.; Chen, G. R.; Sive, H.; Bartel, D. P. Poly(A)-tail profiling reveals an embryonic switch in translational control. Nature 2014, 508, 66-71.

(81) Politz, J. C.; Taneja, K. L.; Singer, R. H. Characterization of hybridization between synthetic oligodeoxynucleotides and RNA in living cells. Nucleic Acids Res. 1995, 23, 4946-4953.

(82) Wang, D. O.; Matsuno, H.; Ikeda, S.; Nakamura, A.; Yanagisawa, H.; Hayashi, Y.; Okamoto, A. A quick and simple FISH protocol with hybridization-sensitive fluorescent linear oligodeoxynucleotide probes. RNA 2012, 18, 166-175.

(83) Gebhardt, A.; Habjan, M.; Benda, C.; Meiler, A.; Haas, D. A.; Hein, M. Y.; Mann, A.; Mann, M.; Habermann, B.; Pichlmair, A. mRNA export through an additional cap-binding complex consisting of NCBP1 and NCBP3. Nat Commun. 2015, 6, No. 8192.

(84) Labade, A. S.; Karmodiya, K.; Sengupta, K. HOXA repression is mediated by nucleoporin Nup 93 assisted by its interactors Nup188 and Nup205. Epigenet. Chromatin 2016, 9, 54.

(85) Sabale, P. M.; Ambi, U. B.; Srivatsan, S. G. A lucifer-based environment-sensitive fluorescent PNA probe for imaging poly(A) RNAs. ChemBioChem 2018, 19, 826-835. 